\title{
Buying and Selling Law Books in Qing Beijing
}

\author{
Ting Zhang \\ University of Maryland \\ zhangting63@gmail.com
}

\begin{abstract}
Beijing was an emerging legal publishing center in late imperial China and at least 60 commercial editions of law books were published there in the Qing. Beijing commercial publishers established close connections with the central government, which enabled them to obtain internal legal and administrative information and to print it for profit. Thanks to their close connections with other printing centers in places like Jiangnan and Jiangxi, Beijing publishers had convenient access to fine editions of legal books in the national book market. In the early 19th century when Jiangnan editions rose to dominance, Beijing publishers adjusted their publishing strategies by republishing Jiangnan editions and reducing the number of their own editions. During the Taiping war, Beijing publishers took the opportunity to expand their business. In the late Qing, Beijing was a flourishing legal printing center, selling a variety of legal books at affordable prices to readers who wanted to learn the law.
\end{abstract}

\section{Keywords}

law books - legal information - commercial publishers - bookstores - Liulichang Wuyingdian - Jiangnan - official directory shop (jinshen $p u$ ) - the national book market - networks of publishers

* My thanks to Tobie Meyer-Fong, William Rowe, Cynthia Brokaw, Emily Mokros, Tongyun Yin, and the two anonymous reviewers for aid and advice in preparing this article. This research was assisted by fellowships from the Henry Luce Foundation/ACLS Program in China Studies, the Doris G. Quinn Foundation, the Chiang Ching-kuo Foundation, the China Scholarship Council, the University of Maryland at College Park, and the Johns Hopkins University. 
After working in Beijing for over twenty years, Yanchang 延昌 (dates unknown), a Manchu official, left the capital for his new appointment as a prefect in Xunzhou 潯州, Guangxi, in 1879. When he set out, Yanchang carried at least $5^{1}$ different books with him. These books covered a variety of genres, including imperial edicts, ritual handbooks, history, geography, dictionaries, encyclopedias, literature, and medical books. The largest portion (around 30\%) of these books, however, belonged to the category of legal books. Yanchang not only brought published versions of the dynastic laws and administrative regulations, such as the Great Qing Code (Da Qing lüli 大清律例) and the Regulations on administrative sanctions of the Six Boards (Liubu chufen zeli 六部處分則例), but also carried a variety of collections of case precedents, legal handbooks, and official handbooks that contained substantial legal information, such as the Brief guide to statutes and substatutes (Lüli bianlan 律例便覽), the Chart of statutes (Lübiao 律表), and the Book for magistrates (Muling shu 牧令書). ${ }^{1}$ As a prefect, Yanchang would have to deal with legal cases on a daily basis, and he needed these law books as reference material. He worried that he would not be able to find them in Xunzhou, an underdeveloped prefecture in remote Guangxi Province. As he wrote: 'Xunzhou has few bookstores, and the categories of books [sold there] are limited; I must take as many books as possible from the capital. ${ }^{2}$

Yanchang recorded the list of book titles in 'Books prepared to carry [on a journey]' in Essentialknowledge for administrative affairs (Shiyixuzhi 事宜須知). In this official handbook, he suggested to his fellow officials that it was necessary to buy enough books in Beijing and take them to provincial posts, especially those in remote and less-developed regions like Xunzhou. Yanchang's thinking was far from exceptional. As the capital of the Qing empire, Beijing was a place where a large number of officials and literati gathered, including thousands of officials and clerks working in the central government, examinees and students from all around the empire, provincial and local officials who

1 Yanchang took the following law books with him: (1) Dynastic laws: Da Qing lüli 大清律 例, Da Qing huidian 大清會典; (2) Administrative regulations: Liubu chufen zeli 六部處分 則例, Gebu gesi zeli 各部各司則例, Libu xinding baoju zhangcheng 吏部新定保舉章程; (3) Collections of case precedents: Qiushen shihuan bijiao 秋審實緩比較, Bo'an xinbian xubian 駁案新編續編; (4) Legal handbooks:Junwei daoli biao 軍衛道里表, Lüli bianlan 律例 便覽, Mingfa zhizhang 名法指掌, Lübiao 律表; (5) Forensic handbooks: Xiyuanlu xiangjie 洗冤錄詳節; (6) Official handbooks that contain detailed legal knowledge:Juguan rixing lu 居官日省錄, Fuhui quanshu 福惠全書, Muling shu 牧令書. Yanchang, Shiyi xuzhi, juan 1, 9a-11a, reprinted in Guanzhen shu jicheng bianzuan weiyuanhui, ed., Guanzhen shu jicheng (Hefei: Huangshan shushe, 1997), 9: 7-8.

2 Ibid., juan 1, 11a. 
came for imperial audiences, expectant officials waiting for appointments, and so on. All of these men frequented the capital's bookstores. Many officials and literati mentioned in their writings that they often visited bookstores, where they searched for and bought books, spent leisure time, and socialized with friends. The concentration of officials and literati, who were the main potential readers in late imperial China, contributed to the development of Liulichang 琉璃廠 Street as the largest book, antique, and art market in North China, if not the largest in China.

Previous research on Liulichang, mostly in Chinese, has focused on literati bibliophiles and their activities, as well as bookstores that sold expensive rare books. ${ }^{3}$ Recently, scholars have begun to pay attention to publishing activities in Liulichang, but most of them have focused on the production and circulation of official directories (jinshen lu 搢紳錄). ${ }^{4}$ No previous scholars have focused their attention on law books - one of the main categories of books commercially published in Beijing. The term 'law books' in this article refers to books related to laws, regulations, and precedents that officials like Yanchang would use in judicial administration, such as the Code, collections of substatutes and regulations, guides to laws and regulations, collections of case precedents, legal treatises, forensic handbooks, official handbooks with detailed legal instructions, and so on. Thus far I have collected 60 different legal books commercially published in Qing Beijing from several major libraries in China, the U.S., and Japan. ${ }^{5}$ These 60 extant editions are probably only a small proportion of the law books that Beijing bookstores published in the Qing period. Although they cannot be viewed as a fully accurate representation of the printing of law books in Qing Beijing, I will try to reach some tentative conclusions based on them. In this article, I will explore the editing, printing, and

3 For example, see Wang Yeqiu, Liulichang shihua, Sun Donghu, Liulichang, and Chen Chongyuan, Liulichang shihua.

4 For general discussions on the production of books in Liulichang, see Feng Wei, 'Qingdai Beijing Liulichang keshu yanjiu', unpublished MA thesis, and Christopher A. Reed, 'Dukes and nobles above, scholars below: Beijing's old booksellers' district Liulichang, 1769-1941—and its influence on 2oth-century Shanghai's book trade', East Asian Publishing and Society 5 (2015): 74-128. On the publications of official directories, see Liu Qiang, 'Ronglu tang yu Qingdai jinshen lu zhi chuban', Tushuguan zazhi 27.10 (2008); Kan Hongliu, 'Jinshen lu yu Qingdai Beijing', Beijing dang'an 10 (2013); and Liu Cheng-yun, 'Anji jincheng yulan yu Qingdai jinshen lu de kanxing', in Zhongyang yanjiuyuan lishi yuyan yanjiusuo jikan 87.2 (2016).

5 The libraries include the National Library of China, the Library of the Institute of Oriental Culture at the University of Tokyo, the Library of Congress, the Harvard-Yenching Library, and the HathiTrust Digital Library. I also refer to Pierre-Étienne Will's forthcoming comprehensive survey of Qing official handbooks and legal treatises: Will, Official handbooks and anthologies of imperial China: a descriptive and critical bibliography. 
marketing of commercially produced legal books in Qing Beijing, with a focus on publishers of law books in Liulichang and their interactions with official publishing houses (e.g., the Wuyingdian 武英殿 Imperial Publishing House) and with commercial publishers in provinces, especially those in the Jiangnan 江南 area. The article will also shed light on the functioning and operation of ordinary book publishers in Beijing through the lens of legal books.

\section{The Rise of Beijing Legal Publishing Industry}

Beijing was a rising printing center of legal books in late imperial China. Official and commercial publishing houses began to produce law books actively in the Ming period. The Classics Depots (Jingchang 經廠), the major printing house of the Ming court, published many official editions of legal books, such as the Grand pronouncements (Dagao 大誥), the Great Ming Code (Da Ming lü 大明 律), and the Great Ming orders (Da Ming ling 大明令). ${ }^{6}$ There were also some commercial publishing houses in Ming Beijing: Zhang Xiumin 張秀民 has identified at least 13 commercial publishing houses, many located in the inner city near the Da Ming 大明 gate. Among them, only the Chen family (Chenshi 陳氏) publishing house located on the street of the Board of Punishments engaged in publishing legal books. It printed the Great Ming Code, the Direct citations of the brief guide for statutes (Lütiao bianlan zhiyin 律條便覽直引), as well as some administrative regulations and official handbooks. ${ }^{7}$

Both official and commercial publishing activities operated on a much larger scale in Qing Beijing than they had in the Ming. The Wuyingdian imperial publishing house printed most of the imperial editions of books relating to laws and regulations. Legal books officially published in Qing Beijing far outnumbered those in the Ming period. The Wuyingdian published at least 7 imperial editions of the Great Qing Code, 18 editions of Expanded substatutes of the Great Qing Code (Da Qing lü xuzuan tiaoli 大清律續纂條例), as well as the various editions of Collected statutes of the Great Qing (Da Qing huidian 大清會典), imperial edicts, administrative regulations, and so on. ${ }^{8}$

The number of commercial publishers and bookstores in Beijing skyrocketed in the Qing period. In the early Qing, book peddling and temporary bookstalls (shutan 書攤), which usually gathered at temple fairs and civil service

6 Zhang Xiumin, Zhongguo yinshua shi (Shanghai: Shanghai renmin chubanshe, 1989), 353-4.

7 Ibid., 359-6o. Du Xinfu and Du Tongshu, Quan Ming fensheng fenxian keshu kao (Beijing juan) (Beijing: Xianzhuang shuju, 2001), 7-8.

8 Ting Zhang, 'Information and power: printing, law, and the making of Chinese legal culture, 1644-1911', unpublished Ph.D. dissertation (Johns Hopkins University, 2014), 39. 
examination events, seem to have been the main methods of bookselling in Beijing. ${ }^{9}$ Regular bookstores were few, and commercial publishing activities were limited. But this situation began to change in the mid-Qing period. More and more book merchants established regular bookstores. A large percentage of these bookstores began to cluster in the Liulichang area, to the south of the Xuanwu 宣武 gate, where a large number of officials and literati gathered. Modern scholars estimate that more than 200 bookstores operated in Qing Beijing. Among them, 135 bookstores were in the Liulichang area, 12 in the Longfu si 隆福寺 area, and 7 in the Damo chang 打磨廠 area; the locations of the others remain unknown. ${ }^{10}$ Although many bookstores focused on selling old and rare books, a large percentage (114 out of 200) of Beijing bookstores engaged in printing or publishing activities. ${ }^{11}$ Books printed in Beijing cover almost every major genre of traditional Chinese books, including classics, histories, literature, collective works, dictionaries, primers, medical books, examination aids, religious books, official directories, tourist guides, legal books, and so on. ${ }^{12}$

Thus far I have found at least 60 different legal books commercially published in Qing Beijing. These books covered almost all the main categories of books relating to laws and regulations, including: (1) Various editions of the Great Qing Code, such as the Expanded comprehensive complete compilation of the Great Qing Code (Da Qing lüli zengxiu tongzuan jicheng 大清律例 增修統纂集成) and the Newly revised comprehensive compilation of the Great Qing Code (Da Qing lüli chongding huitong xinzuan 大清律例重訂會通新纂); (2) Compilations of laws and regulations, such as the Complete collection of substatutes and regulations (Dingli quanbian 定例全編) and the Complete collection of new substatutes (Xinli quanbian 新例全編), (3) Administrative regulations, such as the New compilation of administrative regulations of the Six Boards (Liubu zeli xinbian 六部則例新編); (4) Official and private legal secretary handbooks that included instructions on laws and judicial administration, such as the Complete book concerning happiness and benevolence (Fuhui quans$h u$ 福惠全書), and the Bookfor magistrates; (5) Legal handbooks, including the Brief guide for judging criminal cases (Zheyu bianlan 折獄便覽), the Brief guide to statutes and substatutes, and the Chart of statutes; (6) Forensic handbooks, such as Comprehensive explanations for the washing away of wrongs (Xiyuanlu xiangyi 洗冤錄詳義); and (7) Collections of case precedents, such as Cases memorialized or refuted in our dynasty (Benchao tibo gong'an 本朝題駁公案).

9 Sun Dianqi, Liulichang xiaozhi (Beijing: Beijing guji chubanshe, 1982), 3-4.

10 Beijingshi difangzhi bianzuan weiyuanhui ed., Beijing zhi: chuban zhi (Beijing: Beijing chubanshe, 2005), 446.

11 Feng Wei, 'Qingdai Beijing Liulichang keshu yanjiu', 25.

12 Ibid., 30-2; see also Christopher Reed, 'Dukes and nobles above, scholars below', 123-4. 
As far as I know, no commercial editions of law books produced in Beijing in the Shunzhi period, if there were any, have survived (See Table 1). The earliest extant editions of my sample of 60 Beijing legal books belong to the mid-and late-Kangxi period. Beijing bookstores published at least three editions of law books in the Kangxi period, including the Complete book of the Great Qing Code with extensive collection of vermilion annotations (Da Qing lü zhuzhu guanghui quanshu 大清律朱注廣匯全書), sold by the Wan'gu zhai 萬古齊 bookstore in Liulichang; ${ }^{13}$ the Complete collection of substatutes and regulations, published by the Rongjin tang 榮錦堂 in 1715; and Cases memorialized or refuted in our dynasty, also published by the Rongjin tang in 1720 .

Qing scholars recorded that Beijing's book market began to thrive in the high Qing period, especially during the Qianlong period. The Qing court organized massive book-editing projects in Beijing, including the compilation of the famous the Complete library in four sections (Siku quanshu 四庫全書). These imperial book projects brought many resources from all around the empire to Beijing: literati-editors, woodblock carvers, rare editions of books, and so on. Weng Fang'gang 翁方綱 (1733-1818), a Beijing native and one of the

TABLE 1 The number of commercial legal publications in Qing Beijing

\begin{tabular}{lc}
\hline Reign (dates) & Number of legal publications \\
\hline Shunzhi $(1644-1661)$ & 0 \\
Kangxi $(1662-1722)$ & 3 \\
Yongzheng $\left(1723^{-1735)}\right.$ & 2 \\
Qianlong $(1736-1795)$ & 4 \\
Jiaqing $(1796-1820)$ & 3 \\
Daoguang $(1821-1850)$ & 7 \\
Xianfeng $(1851-1861)$ & 2 \\
Tongzhi $(1862-1874)$ & 8 \\
Guangxu $(1875-1908)$ & 24 \\
Xuantong (1909-1911) & 1 \\
Date unknown & 6 \\
Total & 60 \\
\end{tabular}

13 Wan'gu zhai zhuren, Da Qing lü zhuzhu guanghui quanshu (Beijing: Wan'gu zhai, nd [Kangxi period]). See also Su Yigong, 'Faxue suo guancang Da Qing lü tiyao', in Falü wenxian xinxi yu yanjiu 4 (2007): 9 . 
editors of the Complete library in four sections, wrote that editors usually went to Liulichang bookstores to search for relevant books when they got their editing assignments. ${ }^{14}$ The surge in demand in the high Qing contributed to the development of Beijing's bookstores. Li Wenzao 李文藻 (1730-1778), a midQing official and bibliophile, recorded that there were at least 30 bookstores in Liulichang when he visited Beijing in 1769 - the number of Beijing bookstores had clearly increased significantly from the late-Ming to the high Qing. ${ }^{15}$

Commercial legal publications, however, seems not to have increased at the same pace as the booming Beijing book market in the high Qing. Among the 60 legal books, three were produced in the Kangxi period, two in the Yongzheng period, and four in the Qianlong period (See Table 1). Beijing commercial publishers produced only nine editions of legal books in the long eighteenth century, which consisted of less than $15 \%$ of the 60 legal books. One possible reason for the lower-percentage of high Qing law books is that later books have higher survival rates. Another possible reason is the strong government control and strict censorship in the high Qing, which might have led to the stagnation of commercial legal publishing activities. For example, in 1725, the Yongzheng emperor banned commercial publication of books related to administrative regulations. ${ }^{16}$ In 1740 , the Qianlong emperor launched a nation-wide campaign to ban 'secret handbooks for litigation masters' (songshi miben 訟師秘本). ${ }^{17}$ Although other genres of legal books were not the target of this campaign, the tightening control on legal publications might have discouraged commercial legal publishing activities-Beijing's publishers probably directly sensed the impact of government policies because of their close connections with the court and the central government. Moreover, official legal publications flourished in the high-Qing period. ${ }^{18}$ The Wuyingdian published a large number of high-quality legal books, which reduced the demand for commercial editions among readers. Commercial legal publishing was not only unprofitable but also politically dangerous, and thus many high Qing commercial publishers in Beijing were reluctant to publish legal books.

\footnotetext{
14 Sun Dianqi, Liulichang xiaozhi, 4.

15 Li Wenzao, 'Liulichang shusi ji', in Sun Dianqi, Liulichang xiaozhi, 100-2.

16 Qing shilu (Beijing: Zhonghua shuju, 1985) 7: 513-4.

17 Laibao 來保 and Liu Haolong 劉吴龍, “Tiwei huiyi Sichuan Anchashi Li Rulan zoucheng fangsi zhizhong kanmai songshi miben dengshu yiti chajin xiaohui shi' 題為會 議四川按察使李如蘭奏稱坊肆之中刊賣訟師秘本等書一體查禁銷毀事, in the Lufu zouzhe database in Qingshi bianzuan weiyuanhui 清史編纂委員會, Archive No. 02-01-07-14078-007.

18 Ting Zhang, 'Information and power', 34-42.
} 
The number of commercially published legal books began to rise starting in the Daoguang period. Among the 6o legal books, seven were published in the Daoguang reign, two in the Xianfeng reign, and eight in the Tongzhi reign. The number of extant editions surged to 24 in the Guangxu reign, which comprised more than one-third of all the editions (See Table 1). Several factors might have contributed to the boom in commercial legal printing in Beijing in the late Qing. First, the government loosened control over private or commercial publication of legal and administrative information, which provided space for the development of commercially printed legal books. ${ }^{19}$ Second, the Wuyingdian imperial publishing house began to decline after the Qianlong reign, because of budget cuts and mismanagement. The quality and quantity of the Wuyingdian books declined and they could no longer meet readers' needs, so commercially printed legal books flourished and filled the gap. ${ }^{20}$ Third, the late Qing government placed more and more emphasis on legal training for officials. In 1866, the Qing court established by far the strictest requirements in late imperial history for the examination of newly-appointed officials' legal knowledge: all new officials appointed in the capital had to pass a test on their legal and administrative knowledge. If they failed the test, they would be sent back to the Board of Civil Office to wait for another official opening. Similar legal examinations for expectant officials were also held in provincial capitals. Some extant test reports indicate that the legal tests were in effect until at least the early Guangxu period. ${ }^{21}$ Under the pressure of these new tests, the demand for legal books increased.

Another important reason for the legal publishing boom in late Qing Beijing was probably the impact of the Taiping War (conventionally dated 1850-1864) on Jiangnan, the traditional legal publishing center in late imperial China. This massive civil war devastated many important centers that had produced

19 See Emily Mokros, 'Reading the guides, directories, manuals, and anthologies of Liulichang', in this volume. Moreover, based on extant editions, we see a surge of commercial editions of the Code after the 179os. Many high-ranking officials endorsed these commercial legal publications. Even the strictly-banned 'litigation masters' handbooks' were reprinted in rising numbers after the Qianlong reign. These trends indicate the relaxation of the high-Qing ban on legal publications in the late Qing. See Ting Zhang, 'Information and power', 99-126.

20 Ting Zhang, 'Information and power', 66-9. For the decline of the Wuyingdian, see also Zhu Saihong, 'Qing wanqi Wuyingdian Xiushuchu "xiushu” yu "fei xiushu” zhi'neng de xiaozhang-jiyu Qinggong dang'an de kaocha', Zhongguo chubanshi yanjiu 2 (2015): 137-46.

Qing shilu, vol. 49, 109. See also Ting Zhang, 'Information and power', 165-6. 
commercial legal publications, such as Suzhou and Hangzhou. ${ }^{22}$ The war also destroyed many books and their printing blocks. ${ }^{23}$ When Jiangnan publishers went into decline as a result of the war, Beijing bookstores took the opportunity to expand their business. Take commercial publications of the Code, for example. Before the war, Hangzhou was the unchallenged printing center of commercial editions of the Code, with publishers there producing around 20 different editions between the 1790 s and the 1840 . Bejing, in the same period, only published three editions, all of which were reprinted copies based on Hangzhou editions. During and immediately after the Taiping War, while Hangzhou published only two editions, Beijing published at least four editions. Even though Jiangnan legal publishers gradually regained their advantage after the war, Beijing maintained its new position as an important commercial legal publishing center, with the publication of at least 35 different editions of legal books from the Xianfeng reign to the fall of the Qing in 1911 (See Table 1).

\section{Commercial Legal Publishers in Qing Beijing}

Most commercial publishers of legal books in Beijing clustered in the Liulichang area. Based on the front colophon pages of the 60 legal books in my sample, I can identify 18 publishing houses. Ten of these were in the Liulichang area, including the Wan'gu zhai, the Rongjin tang, the Tongsheng ge 同陡閣, the Jindong shuhang 金東書行, the Longwen zhai 龍文齊, the Shancheng tang 善成堂, the Ronglu tang 榮錄堂, the Longyun zhai 龍雲齋, the Wenhua tang 文華堂, and the Hanmao zhai 韓茂齋. Three of these 18 publishers were in the Longfu si area in the inner city, including the Tongli tang 同立堂, the Baoshu tang 寶書堂, and the Wensheng tang 文盛堂. One publisher-the Rongsheng tang 榮陸堂—was in Yangmeizhu xiejie 楊梅竹 斜街, just a few blocks to the east of Liulichang. One publisher did not reveal its name but mentioned its location-'the No. 7 official house in the Shangxie Street outside the Xuanwu Gate, to the west of the bridge' (Xиanwu men

22 For Suzhou and Hangzhou's role in Qing legal publishing industry, see Ting Zhang, 'Marketing legal information: commercial publications of the Great Qing Code, 1644-1911', in Li Chen and Madeleine Zelin, eds., Chinese law: knowledge, practice, and transformation, 1530 s to 1950 (Leiden: Brill, 2015), 245-8. Ting Zhang, 'Lüdian, muyou, yu shushang: lun Qingdai Jiangnan falü shuji de chuban yu liutong', Zhejiang daxue xuebao 45.1 (2015), 51-8.

23 For example, see Tao Jun and Tao Nianlin, eds., Da Qing lüli zengxiu tongzuan jicheng (Hangzhou: Juwen tang, 1907), 'Preface', 6ob-61a. 
wai qiaoxi shangxie jie diqisuo guanfang 宣武門外橋西上斜街第七所官房), around one mile to the west of Liulichang. Four publishers - the Yude tang 毓德堂, the Shenyi tang 慎怡堂, the Jingdu shuju 京都書局, and the Wenbao tang 文寶堂—did not indicate their location. Some books did not reveal their publishers, only mentioning that they were published in 'Liulichang in the capital' (Jingdu Liulichang 京都琉璃廠) or just 'the capital' (Jingdu 京都).

A large percentage of bookstores that published legal books belonged to the category of 'official directory shop' (jinshen $p u$ 搢紳鋪), including the Rongjin tang, the Tongsheng ge, the Ronglu tang, the Wenhua tang, the Wenbao tang, and the Rongsheng tang. ${ }^{24}$ Unlike the many bookstores in Liulichang that focused on the business of selling expensive rare books, these 'official directory shops' published and sold new books. Although their main business consisted of printing the official directories, which recorded information about current officials, including their names, levels of degree, ranks, and native places, official directory shops often engaged in publishing legal books. The Rongjin tang, for example, an influential official directory shop active in the mid-Qing period, published at least five legal books, including the Complete collection of substatutes and regulations (1715), Cases memorialized or refuted in our dynasty (1720), Newly added substatutes of the complete collection of substatutes and regulations (Dingli quanbian xuzeng xinli 定例全編續增新例, 1723), the Extended compilation of statutes and regulations (Dingli xubian 定例續編, 1745), and the Extended guide for judicial and financial affairs (Zengding xingqian zhizhang 增訂刑錢指掌). Based on the list of the Rongjin tang's extant publications, it seems that it mainly focused on publishing two genres of books, official directories and legal books. The Ronglu tang, an active official directory shop in the late Qing, also engaged in printing and selling legal books. Regarding the number of publications, the Ronglu tang was one of the most important publishers in Liulichang. Emily Mokros estimates that the Ronglu tang published at least 458 different editions of official directories. It also published and sold numerous editions of law books, including a variety of new substatutes, administrative regulations, collections of case precedents, legal and administrative guides for officials, forensic handbooks, and so on (See Table 2$) \cdot{ }^{25}$ In

\footnotetext{
24 For the list of official directory shops in Beijing, see Liu Cheng-yun, 'Anji jincheng yulan yu Qingdai jinshen lu de kanxing', 359-61.

25 Emily Mokros estimates that the Ronglu tang published 22 law books: Mokros, 'Communication, empire, and authority', unpublished Ph.D. dissertation (Johns Hopkins University, 2016), 151-3. According to the publication list in Ronglu tang's own advertisement in 1892, it published and sold 16 different legal books: Jinshen quanshu (Beijing: Ronglu tang, winter 1892), front advertisement page.
} 
one of its advertisements, the Ronglu tang announced that it concentrated on printing (zhuanke 專刻) all kinds of administrative books (lishu 例書) and new regulations issued by the Six Boards. ${ }^{26}$

Since legal books and official directories were targeted at the same group of readers, official directory shops printed and sold these two genres of books together. Potential readers of official directories, as Kan Hongliu has pointed out, included officials, scholars, and merchants in Beijing. Newly-appointed officials, expectant officials waiting for appointments, and examinees who came to Beijing for the civil service examinations were most likely to buy official directories. They used the books to search for possible social connections, to commemorate their appointments or promotions, or to give them to their friends and fellow officials as souvenirs from Beijing. ${ }^{27}$ While shopping in the official directory shops, they would also have the opportunity to purchase legal books, which might be quite useful for their future administrative and judicial roles. For example, when Yanchang left Beijing, in addition to legal books, he also took with him some 'large and small editions of official directories' and later sent them as gifts to his superior officials in Guangxi. ${ }^{28}$ Although Yanchang did not specifically mention where he bought his books, he most likely bought them at official directory shops, such as the Ronglu tang.

Besides official directory shops, some 'character-carving shops' (kezi pu 刻 字鋪) — printers specialized in carving blocks and printing books—also published some legal books. The Longyun zhai 龍雲齋, for example, was a character-carving shop in Liulichang famous for carving stelae and woodblocks of high quality. ${ }^{29}$ It printed at least two official handbooks, A must-read book for officials (Juguan bidu shu 居官必讀書) by Yao Kaiyuan 姚凱元 (dates unknown) and Essential principles for officials (Juguan yaoze 居官要則) by Chen Qingzi 陳慶滋 (dates unknown). ${ }^{30}$ Another renowned character-carving shop in the late Qing, the Hanmao zhai 翰茂齋 in Liulichang, printed the influential legal treatise by Xue Yunsheng 薛允升 (1820-1901), Doubts remaining after perusing the substatutes (Duli cunyi 讀例存疑), in 1905. While official directory shops can be considered to have been fully-fledged publishers, undertaking the printing, publishing, and selling of their legal books, character-carving

\footnotetext{
26 Jinshen quanshu (winter 1892), front advertisement page.

27 Kan Hongliu, 'Jinshen lu yu Qingdai Beijing', 57.

28 Yanchang, Shiyi xuzhi, juan 1, 12a.

29 Zhongguo renmin zhengzhi xieshang huiyi Beijingshi weiyuanhui wenshi ziliao yanjiu weiyuanhui, ed., Wenshi ziliao xuanbian (Beijing: Beijing chubanshe, 1984), 19: 301.

$30 \quad$ Yao Kaiyuan, Juguan bidu shu (Beijing: Longyun zhai, nd); Chen Qingzi, Juguan yaoze (Beijing: Longyun zhai, nd).
} 
shops, on the other hand, printed books on demand for authors and their relatives and friends who would pay for the cost of printing. For example, Xue Yunsheng's friends and colleagues raised funds to have the Hanmao zhai print Doubts remaining after perusing the substatutes. ${ }^{31}$ The quantity of legal publications produced by character-carving shops cannot compare with that of the official directory shops - character-carving shops seldom printed more than one or two legal books and their printing activities were not focused on legal books. The quality of their printing, however, was usually much higher than the quality of books produced in bulk by the official directory shops.

In addition to the official directory shops and character-carving shops, there were also a number of ordinary bookstores in Beijing which occasionally published legal books, including the Baoshu tang, the Shancheng tang, the Wensheng tang, the Shenyi tang, and the Tongli tang. They did not focus on publishing legal books or official directories but occasionally printed a title or two and sold these books for profit. For example, the Wensheng tang in the Longfu si area focused on printing a variety of genres of books in Manchu, including dictionaries, handbooks, and fiction. Among its publications, we find Terminology of the Six Boards in Manchu and Chinese (Man Han liubu chengyu 滿漢六部成語), which belongs to the category of legal and administrative handbooks. Another example is the famous Shancheng tang in Liulichang. The publications of this comprehensive publisher covered various genres including medical books, classics, history, examination aids, and so on. It also published and sold at least two commercial editions of the Great Qing Code in 1877 and $1888 . .^{32}$

\section{Editing and Publishing Legal Books in Qing Beijing}

In 1715, Li Zhen 李珍 (dates unknown), the owner of the Rongjin tang official directory shop in Liulichang, published his first legal book, the Complete collection of substatutes and regulations. Li was a book merchant from Xiugu 繡谷 town in Jinxi 金溪 county, a flourishing printing center in Jiangxi. Li wrote in the preface that his business concentrated on printing and selling official directories, but he liked reading statutes and substatutes in his spare time. He noticed that the Qing court frequently issued new substatutes and regulations, but these numerous new laws were dispersed in official documents in the Six Boards, and thus 'gentlemen who had not yet been appointed

31 Xue Yunsheng, Duli cunyi (Beijing: Hanmao zhai, 1905), 'Shen Jiaben’s Preface'.

32 Da Qing lüli huiji bianlan (Beijing: Shancheng tang, 1877 and 1888). 
as officials' (weishi junzi 未仕君子) had no channels through which to read them. He claimed that previous commercial publications about the laws were incomplete. Therefore, Li decided to compile a complete book on laws and regulations on his own. His main sources were three published collections of laws and regulations, all compiled by private legal secretaries from Jiangnan and printed in the late Kangxi period. ${ }^{33}$ Li Zhen followed the categories of the official edition of Collected statutes of the Great Qing when sorting laws and regulations in his book. ${ }^{34}$

It took Li one year to finish compiling the book, and when complete it was a comprehensive collection of statutes, substatutes, and regulations of the Qing dynasty. Besides the four books mentioned above, Li Zhen announced on the front page of the book that he included information from the following books and documents: Current administrative regulations of the Six Boards (Liubu xianxing zeli 六部現行則例), New substatutes extended and enlarged (Xuzeng zeli 續增則例), Treatises on the management of military affairs (Zhongshu zhengkao 中樞政考), newly established substatutes suggested by the Boards in recent years, and notices in response to inquiries from governors-general and governors after combined discussions in the Six Boards (gesheng dufu zixun Liubu heyizifu zhizhao 各省督撫諮詢六部合議諮覆知照). He also promised that he would update the book quarterly by adding new substatutes and regulations. ${ }^{35}$ Li Zhen's book, therefore, was a combined compilation based on both published legal books and unpublished 'internal' documents that circulated within the Qing bureaucracy. It was a huge book, containing 50 chapters divided into 32 volumes.

Li Zhen worried that his status as a bookstore owner did not provide enough credibility for this compilation of laws and regulations. He asked a relativethe famous official and Hanlin Academician $\mathrm{Li} \mathrm{Fu}$ 李紱 (1675-1750)— to write a preface for the book. Li Fu ardently endorsed the reliability of the book and praised it for providing readers with access to the most current laws and regulations. He argued that all officials, as well as scholars who intended to be officials in the future, should purchase and read the book. ${ }^{36}$ In order to reduce

33 These three books are: Lu Hai, Benchao zeli leibian; Sun Lun, Dingli cheng'an hejuan; and Tang Juye, Benchao xuzeng zeli leibian. For detailed information about these three books, see Kishimoto Mio, 'Guanyu Qingdai qianqi dingli ji de liyong', in Xu Shihong, ed., Zhongguo gudai falü wenxian yanjiu (Beijing: Shehui kexue wenxian chubanshe, 2014), 8: $378-80$.

34 Li Zhen, Dingli quanbian, 'Statement of compilation' (bianshu 編述), 1b-2a.

35 Ibid., front page.

$36 \quad$ Ibid., Dingli quanbian, 'Li Fu's preface', за-5a. 
the cost of printing, after editing and proofreading the book, Li Zhen took the manuscript to Jiangnan, where he had a printer carve the woodblocks and print the book. ${ }^{37}$

The example of Li Zhen reveals how Beijing bookstores edited, printed, and published legal books in the early and mid-Qing period. Bookstore owners played an important role in compiling legal books. Besides the Complete collection of substatutes and regulations, Li Zhen compiled at least two other legal books: Cases memorialized or refuted in our dynasty (1720) and Newly added substatutes of the complete collection of substatutes and regulations. Two other Xiugu natives, Li Tai 李泰 (dates unknown) and Li Sen 李森 (dates unknown) of the Tongsheng ge bookstore in Liulichang, also participated in the compilation of legal books. ${ }^{38}$ Bookstore owners also used their connections to solicit manuscripts and prefaces. For example, the Rongjin tang published the Extended compilation of substatutes and regulations in 1745, about 30 years after the publication of The complete collection of substatutes and regulations. The editor of this new collection of substatutes was a private legal secretary named Liang Maoxiu 梁禁修 (dates unknown), who came from Gao'an 高安 county in Jiangxi Province and sojourned in Beijing. ${ }^{39}$ Liang Maoxiu mentioned that he collected new substatutes and regulations from the Peking gazette (dichao 邸 抄) for his own use, but when 'a bookseller friend' (fangyou 坊友) heard of the manuscript, he insisted that Liang publish it. ${ }^{40}$ Liang probably got to know the owner of the Rongjin tang while sojourning in Beijing and established a connection because they were both from Jiangxi.

Many Beijing bookstore owners, especially those who managed official directory shops, had convenient access to the latest laws and regulations. When

37 Li Zhen, Dingli quanbian xuzeng xinli (Beijing: Rongjin tang, 1723), front page.

38 See Li Tai, Xinli quanbian (Beijing: Tongsheng ge, 1750) and Li Sen Xuzeng xinli quanbian (Beijing: Tongsheng ge, 1753).

39 Liang Maoxiu's compilation of Dingli xubian, however, is the only case in my sample of 60 books that a private legal secretary directly participated in the compiling and publishing process in Beijing. The connections between private legal secretaries and legal publishing industry varied based on specific locations: in places like Hangzhou, where a large number of private legal secretaries gathered, the rise of commercial editions of law books had direct connections with the rise of power of, as well as the increasing competitions among, private legal secretaries: see Ting Zhang, 'Information and power', chapter 2. In places like Beijing, however, few legal secretaries directly participated in editing and publishing process. Bookstore owners played a far more important role than legal secretaries in compiling and publishing Beijing law books. After all, most Beijing law books, as we will discuss, are reprinted copies based on editions originally published elsewhere. 
updating official directories based on the archives in the Boards, Beijing commercial publishers established connections with officials and clerks in the central government. ${ }^{41}$ These connections also gave commercial publishers access to legal documents and archives in the government. In the late Qing, the connections between Beijing commercial publishers and the central government came even closer. After the 1869 fire that burned down the Wuyingdian and most of its woodblocks and equipment, the Wuyingdian seldom printed new books. ${ }^{42}$ The court 'outsourced' some of its official printing business to commercial publishers. ${ }^{43}$ Beijing commercial publishers printed updated laws and regulations, official directories, civil service examination papers, and official histories such as the Veritable records of the Guangxu reign (Guangxu shilu 光 緒實錄), for the Qing government. ${ }^{44}$ Some bookstores recycled these woodblocks and printed commercial editions of these books. For example, the front colophon page of the 1877 edition of Comprehensive compilation of a convenient guide to the Great Qing Code (Da Qing lüli huiji bianlan 大清律例匯 輯便覽), published by the Shancheng tang bookstore in Liulichang, revealed that this book was printed from 'official woodblocks in the Board in the capital' (Jingdu Bu'nei guanban 京都部內官板). ${ }^{45}$

Another important source of information for Beijing legal books was the Peking gazette. When compiling the Complete collection of substatutes and regulations, Li Zhen largely relied on the Peking gazette to collect newly promulgated substatutes and regulations. When reading the Peking gazette, he also noticed that sometimes the Boards rejected the sentences originally suggested by governors-general and governors and sent the cases back to the provinces for retrials. He thought that these cases were meaningful precedents that would shed light on the application of law in judicial practice. He thus decided

41 For the connections between official directory shops and the government, see Liu Qiang, 'Ronglu tang yu Qingdai jinshen lu zhi chuban', 67, and Liu Cheng-yun, 'Anji jincheng yulan yu Qingdai jinshen lu de kanxing', 349-67.

42 Zhu Saihong, 'Qing wanqi Wuyingdian Xiushuchu', 141-6.

43 Beijing Gongye zhi bianzuan weiyuanhui, ed., Beijing gongye zhi: yinshua zhi (Beijing: Zhongguo kexue jishu chubanshe, 2001), 69 .

44 On Beijing bookstores printing official editions of official directories, see Liu Cheng-yun, 'Anji jincheng yulan yu Qingdai jinshen lu de kanxing', 366-7. On bookstores printing examination papers, see Shenbao 1898.5.26 (No. 9019), 2. As for the publication of Guangxu shilu, see Shenbao 1911.6.4 (No. 13763), 4.

Da Qing lüli huiji bianlan (Beijing: Shancheng tang, 1877), front colophon page. 
to collect these cases from the Peking gazette, which led to the compilation of Cases memorialized or refuted in our dynasty, published in $1720 .{ }^{46}$

The inclusion of updated and 'internal' legal information was an important selling point for Beijing legal books. Many books promised readers that they included the most up-to-date laws and regulations, and many even promised that they would update their books when the government promulgated new substatutes and regulations. In the 'General editorial principles' of the Complete collection of substatutes and regulations, Li Zhen wrote that he would add new substatutes (xinli 新例) quarterly, following the same schedule as the updates of official directories produced and sold in his bookstore. ${ }^{47}$ Many legal books published in Beijing emphasized that they contained newly updated information in their books. They did so by using titles such as the Complete compilation of new substatutes, Newly extended statutes of the Great Qing (Xinzeng Da Qing li 新增大清例), and Newly extended new regulations of the Board of Punishments (Xinzeng Xingbu xinzhang 新增刑部新章), which informed readers that the books contained the most up-to-date information available. ${ }^{48}$ One of the main contributions made by these legal books, as many editors and publishers articulated in their prefaces, was that they made updated laws and regulations easily available to readers, especially newly-appointed officials and scholars outside the official world. Liang Maoxiu, for example, pointed out that it was extremely difficult for new officials to find a complete and reliable collection of updated laws and administrative regulations. His book would fill the gap and bring 'the secret [documents] hidden in [private legal secretaries'] pillows' (zhenzhong zhimi 枕中之密) to readers in the public. ${ }^{49}$

\section{Printing Legal Books in Qing Beijing}

The cost of printing books in Beijing was relatively high. For one thing, Beijing and nearby regions did not produce paper in sufficient quantities, and thus publishers had to purchase paper from southern provinces and transport it

46 Li Zhen, Benchao tibo gong'an, 'Li Zhen's preface': cited from Xu Lizhi, 'Zhongguo shekeyuan faxuesuo tushuguan shanbenshu tiyao', available on-line at http://www.iolaw.org .cn/showNews.asp?id=17309.

47 Li Zhen, Dingli quanbian, 'General editorial principles', 2 b.

48 See Li Tai, ed., Xinli quanbian. Xinzeng Da Qing li and Xinzeng Xingbu xinzhang were mentioned in Ronglu tang's advertisement in Jinshen quanshu (winter 1892), front advertisement page.

Liang Maoxiu ed., Dingli xubian, 'Liang Maoxiu’s preface', 2a. 
to Beijing, which added to the cost. Hu Yinglin 胡應麟 (1551-1602), a late-Ming scholar and bibliophile, noted: 'Printing books in the capital costs three times what it does in Yuezhong 越中 (i.e., Shaoxing and its nearby region), because the paper is expensive. ${ }^{50}$ For another, Beijing was short of skillful woodblock carvers. Wang Shizhen 王士禎 (1634-1711) pointed out: 'When printing books in the capital, good craftsmen are rare! ${ }^{51}$ The consideration of cost was probably the main reason why Li Zhen sent his manuscript to Jiangnan for printing. Beijing publishers often locally printed relatively short books, such as official directories that needed to be frequently updated. It was probably more economical for them to print larger books in the South and to transport them back through the Grand Canal than it was to print them in Beijing. Moreover, most bookstore owners and apprentices in Beijing before the late Qing came from Jinxi, and they had close connections with printers in this booming printing center. ${ }^{52}$ Beijing bookstores managed by Jinxi men usually focused on selling new books rather than used and rare books, and many of these new books were probably printed in Jinxi and sold in Beijing. ${ }^{53}$

The number of skilled craftsmen in Beijing began to increase during the mid-Qing period. The expansion of official and commercial printing activities and higher wages attracted craftsmen from all over the empire to the capital. For the massive imperial printing projects of the high Qing, the court hired hundreds or even thousands of craftsmen, many coming from places outside Beijing, including Shandong, Shanxi, and Jiangnan. ${ }^{54}$ For example, at the time of the imperial project of publishing the Chinese Buddhist canon (Dazang jing 大藏经) in 1736, officials found that there were only 400 woodblock carvers in Beijing, and more than half of them already were working for other central government printing agencies. Only a few of them, therefore, were available to work on the Chinese Buddhist canon. The project managers asked the emperor for permission to hire several hundred craftsmen to come to Beijing, specifically to carve the woodblocks for the Chinese Buddhist canon. ${ }^{55}$ Many craftsmen stayed in Beijing after these imperial publishing projects and worked for commercial publishers. These skilled craftsmen improved the quality of books printed in Beijing. As Zhang Mu 张穆 (1805-1849), a scholar and bibliophile

\footnotetext{
5o Zhang Xiumin, Zhongguo yinshua shi, 361-2.

$5^{1} \quad$ Ibid., $55^{2}$.

$5^{2}$ Sun Dianqi, Liulichang xiaozhi, 16, 102.

53 Feng Wei, 'Qingdai Beijing Liulichang keshu yanjiu', 19.

54 See Yang Yuliang, 'Wuyingdian Xiushuchu ji Neifu xiushu geguan', in Gugong bowuyuan yuankan, 1 (1990): 34 .

55 Feng Wei, 'Qingdai Beijing Liulichang keshu yanjiu', 29.
} 
who sojourned in Beijing in the Daoguang period, commented: 'The woodblock carvers and copyists hired in bookstores in the capital are getting better by the day. 56

An increasing number of publishers chose to carve woodblocks and print books in Beijing in the late Qing period. Most early and mid-Qing legal books published by Beijing bookstores revealed information about the publishers rather than giving the locations of the woodblocks on the front colophon pages: colophons stated, for example, 'Printed and published (zixing 梓行) by the Wensheng tang in the capital' or "Newly carved by the Rongjin tang in the capital.' They did not mention the location of blocks, probably because the blocks were carved and stored outside Beijing in order to reduce the cost of printing, as Li Zhen did when printing the Complete collection of substatutes and regulations. In the late Qing, however, more publishers were willing to indicate the location of their woodblocks, stating, for example, that 'the woodblocks are stored (bancang 板藏) in the Ronglu tang in the capital' or that 'the woodblocks are stored in the Tongli tang in the Longfu si in the capital.' Since these woodblocks were in Beijing, it seems likely that publishers did not only store the blocks, but also carved them—and printed the books—in Beijing as well.

The flourishing commercial publishing business in late Qing Beijing contributed to the formation of a network of printers and publishers. When it came to printing and selling legal books, Beijing bookstores were more likely to cooperate with each other than compete. Many small publishers in Liulichang did not employ craftsmen long-term. Instead, they worked with woodblockcutting shops, many of which were located in Yangmeizhu Street just a few blocks away from Liulichang, to print their books. ${ }^{57}$ When printing huge multivolume books, publishers might collaborate with each other. Shorter legal books printed in Beijing in the late Qing were mostly produced by a single publisher, as indicated in the colophon. Longer multi-volume books, however, tended only to reveal the location where they were printed, such as 'the capital' or 'Liulichang in the capital'. For example, only three of the sixteen commercial editions of the Code - a huge book that usually contained over 40 chapterspublished in Beijing contained information about the publishers. Moreover, in 1893, Beijing publishers reprinted the Complete book concerning happiness and benevolence (32 chapters). The front colophon page, explained that the woodblocks were in the Wenchang Guildhall of Bookstores (Shuhang Wenchang huiguan 書行文昌會館)一the guildhall of Liulichang book merchants; it did

\footnotetext{
56 Zhang Xiumin, Zhongguo yinshua shi, $55^{2}$.

57 Feng Wei, 'Qingdai Beijing Liulichang keshu yanjiu', 29.
} 
not mention any specific publishers. ${ }^{58}$ These large books were probably the product of joint investments by several publishers.

Few bookstores published similar editions in the same period. Scholars have argued that official directory shops in Liulichang cooperated to some extent when publishing official directories. With a few exceptions, only one publisher printed an edition of the official directory each season. ${ }^{59}$ This type of cooperation seems to obtain for the publication of legal books in Beijing, too. Few Beijing publishers printed similar editions of legal books in the same period. This was quite different from publishers in Hangzhou, another legal printing center in the mid and late Qing, where the competition was intense. Many Hangzhou publishers printed and sold similar editions of legal books at similar prices in the same period. They often fiercely attacked each other in advertisements and denounced other publishers for selling unreliable editions of low quality. ${ }^{60}$ Beijing publishers rarely made similar announcements. The majority of Beijing publishers were sojourning book merchants from Jiangxi (in the early and mid-Qing) and Hebei (in the late Qing). They were closely linked by way of native-place connections, which helped them survive and flourish in the complicated environment in the empire's capital. The Liulichang book merchants had their own guildhalls — the Wenchang Guildhall for Jiangxi merchants and the Northern Zhili (Beizhi 北直) Wenchang Guildhall for Hebei natives who rose to power in the late Qing. ${ }^{61}$ The guildhalls regulated commercial publishing activities in Liulichang and to some extent reduced competition among bookstores.

\section{Connections: Liulichang, Wuyingdian, and Jiangnan}

Liulichang book merchants established strong connections with officials and clerks in the Qing government. A late-Qing Hanlin official, Zhang Peilun 張佩綸 (1848-1903), described the owner of the Baoming zhai 寶名齋 bookstore as follows:

$5^{8}$ Huang Liuhong, Fuhui quanshu (Beijing: Shatuyuan Wenchang huiguan, 1893), front colophon page.

59 Liu Qiang, 'Ronglu tang yu Qingdai jinshen lu zhi chuban', 68; Liu Cheng-yun, 'Anji jincheng yulan yu Qingdai jinshen lu de kanxing', 361-2.

6o Ting Zhang, 'Information and power', 146-8.

61 Sun Dianqi, Liulichang xiaozhi, 273, 280. See also 'Beizhi Wenchang huiguan bei', in Li Hua, ed., Ming Qing yilai Beijing gongshang huiguan beike xuanbian (Beijing: Wenwu chubanshe, 1980), 123-7. 
LiZhongming 李鐘銘 ... falsely claims that he is related to He Shouci 賀壽慈, the Minister of the Board of Public Works. Li swindles people under false pretenses, and nothing can stop him. In the capital, he makes friends with everyone from officials in the court to clerks in the Boards. Outside the capital, he connects with high provincial officials as well as lower officials like county magistrates. Sometimes he acts as a proxy (baolan 包撹) to send in accounts to the Board of Revenue. Sometimes he bribes officials in the Board of Civil Office for official selections. Sometimes he helps officials in the capital look for appointments. Sometimes he helps officials outside the capital ask for secret letters ... Everyday high officials and expensive horses crowd at the gate of his mansion. ${ }^{62}$

Zhang Peilun's account vividly depicts a powerful Liulichang book merchant who had close connections with all kinds of officials and clerks in and out of the capital. It was quite common for bookstore owners to cultivate relationships with officials and literati who lived in or visited Beijing: Liulichang bookstores usually had plaques with store names written by celebrated officials and literati, including Zeng Guofan 曾國藩 (1811-1872), Kang Youwei 康有為 (18581927), Lu Runxiang 陸潤庠 (1841-1915), and Weng Tonghe 翁同棆 (1830-1904). The Ronglu tang, the major publisher of official directories and legal books in Liulichang in the late Qing, had its plaque written by the renowned scholarofficial Sun Yijing 孫詒經 (1826-1890). ${ }^{63}$ Some officials even chose to stay in bookstores rather than hotels when they visited Beijing. ${ }^{64}$ Bookstore owners used these carefully cultivated relationships with officials and clerks to buy and sell books, to get access to inside information in the government, and to invite people to contribute prefaces for their publications.

Liulichang bookstores also had close connections with the Wuyingdian imperial publishing house. The Wuyingdian employed only a small number of regular craftsmen: the Brushing and Printing Workshop (Shuayin zuo 刷印作) of the Wuyingdian only had 40 regular craftsmen and the Woodblock

62 Zhang Peilun, 'Shugu Li Zhongming zhaoyao zhuangpian qing quzhu pian', memorial submitted in 1879; cited from Wang Yeqiu, Liulichang shihua, 55 .

63 Sun Dianqi, Liulichang xiaozhi, 38-44.

64 For example, in 1901 the Dong'an 東安 county magistrate came to the capital under the order of Li Hongzhang 李鴻章 to help investigate a legal case. Rather than staying in a hotel, he chose to spend the night in the Ronglu tang bookstore. Shenbao 1901.5.3, No. 10070,3 . 
Carving Workshop (Kezi zuo 刻字作) had only four to six regular craftsmen. ${ }^{65}$ Therefore, the majority of those working for the Wuyingdian were shortterm or temporary craftsmen. Many worked for commercial publishers as well. Liulichang bookstores could get access to Wuyingdian books and woodblocks through these craftsmen. For example, in 1825 the Wuyingdian officials found that someone had broken into the warehouse and stolen eight valuable Wuyingdian editions of books. ${ }^{66}$ After the investigation, Wuyingdian officials found that a bookstore named Wenguang tang 文光堂 in Liulichang was selling these stolen books. They arrested the bookstore owner, who later confessed that he had bought them from four craftsmen working in the Wuyingdian.

Considering Beijing bookstores' close relationships with officials, it is surprising to find that few officials were interested in publishing their works in Beijing, nor did Beijing commercial publishers actively solicit manuscripts from officials. In the early and mid-Qing period, bookstore owners like Li Zhen personally participated in editing and publishing legal books, as we have discussed above. In the late Qing, however, most legal books in Beijing were simply reprinted copies based on books published elsewhere. I have found information about the original places of publication of 44 editions out of my sample of 60 Beijing legal books: of these 44 editions, only 15 (34\%) were originally published in Beijing, and three of these 15 were reprints of previously published Beijing editions. This means that Beijing commercial publishers only produced 12 original editions. Nine editions of my sample of 60 books were published between 1644 and 1800 (See Table 1). Five of these nine early-andmid Qing editions contained clear information about their original publishing places-all indicating that they were from Beijing. The other four editions for which I cannot find definite evidence about their original places were possibly first edited and published in Beijing as well. ${ }^{67}$ Therefore, we may argue that most Beijing legal books published before 1800 originated in Beijing. The situation, however, completely changed in the late Qing. Commercial publishers produced only seven new legal books that were not reprints since the Jiaqing

65 Yang Yuliang, 'Wuyingdian Xiushuchu ji neifu xiushu geguan', Gugong bowuyuan yuankan, 31 .

66 These eight books were: five copies of Book of literary allusions and poetic diction (Peiwen yunfu 佩文韻府), one copy of the Kangxi dictionary (Kangxi zidian 康熙字典), one copy of The Four Classics (Sishu 四書), and one copy of the Rites of the Zhou (Zhouli 周禮). See Mianxin, 'Zou wei Wuyingdian Xiushuchu houku shuji beidao an shi', Archive No. 03-3926-012, in the Lufu Zouzhe Database, available at Qingshi bianzuan weiyuanhui.

67 These four editions include: Wan'gu zhai zhuren., Da Qing lü zhuzhu guanghui quanshu; Liubu zelixinbian (Beijing, 1730); Li Tai, Xinli quanbian; and Li Sen, Xuzeng xinli quanbian. 
reign, which consisted of merely $30 \%$ of Beijing legal books published in the late Qing with known original publishing places. At least three of these seven editions were products of character-carving shops rather than regular commercial publishers. ${ }^{68}$ Commercial publishers in late Qing Beijing thus became much less creative and less original than their early Qing counterparts had been. Although it was a common practice for commercial publishers to reprint previously published editions (Cynthia Brokaw points out that many Sibao books 'were simply copied from editions published elsewhere'), the declining originality of Beijing legal publishers still seems notable, especially in consideration of their convenient access to the pool of potential authors and editors in the capital. 69

The high cost deterred many authors from publishing their books in Beijing. Although the cost of printing in the late Qing in Beijing was probably lower than before, it was still more expensive than in other printing centers. For example, Yang Shoujing 楊守敬 (1839-1915), a late Qing scholar and bibliophile who frequently visited Liulichang bookstores, complained: 'carving woodblocks in the capital is incredibly expensive!' When he heard that his friend Wang Xianqian 王先謙 (1842-1917) printed his books in Yongzhou 永州, Hunan, where the printing was inexpensive and the quality was high, he asked Wang whether he could help him find a printer in Hunan as well. If Wang agreed, he would send a clean copy of the manuscript to Hunan for printing. Since his manuscript was extremely long (over 2,000,00o characters), Yang estimated that printing in Hunan would save him a large amount of money.70 Officials who wanted to publish legal books might face a similar situation. They often chose to print their books in other places where the price was more affordable. Yanchang, for example, published his own official handbook in Guilin 桂林, Guangxi, even though his target audience was mostly officials like him who left Beijing for provincial appointments. ${ }^{71}$ Since few readers in Guilin would be interested in this book, he probably took copies back to Beijing, where he could distribute or sell them.

The decline of Beijing legal publishers' interest in producing new texts was associated with the power dynamics of Qing legal printing culture. Generally speaking, commercial publishers tended to reprint books that had already sold

68 These three editions are Xun Yunsheng, Duli cunyi, Chen Qingzi, Juguan yaoze, and Yao Kaiyuan, Juguan bidu shu.

69 Cynthia J. Brokaw, Commerce in culture: the Sibao book trade in the Qing and Republican periods (Cambridge ma: Harvard University Press, 2007), 309.

$70 \quad$ Yang Xianmei, Yang Shoujing tiba shuxin yigao (Chengdu: Bashu shushe, 1996), 211-2.

71 Yanchang, Shiyi xuzhi, front colophon page. 
well in the market. In the case of legal books, since the main target readers were officials and private legal sectaries, who would rely on these books in their judicial work, authoritativeness and timeliness were the most important selling points. It is surprising that Beijing commercial publishers seldom reprinted legal books based on Wuyingdian editions, which were traditionally viewed as the most authoritative editions in the Qing legal world. This was not because the Qing court did not allow commercial publishers to reprint Wuyingdian editions. On the contrary, the court often encouraged commercial and private publishers to reprint Wuyingdian editions as a means of disseminating orthodox and authoritative information and ideas. ${ }^{72}$

In fact, it was because Wuyingdian editions of legal books were often outdated and thus unpopular among readers that Beijing commercial publishers did not reprint them. Although the Wuyingdian was famous for producing highquality editions of Confucian classics, histories, medical books, and dictionaries, which were popular among readers and usually sold at high prices, legal books published by the Wuyingdian did not sell well. ${ }^{73}$ According to the extant book selling registers, the Book Circulation Bureau (Tongxing shuji chu 通行書 籍處) — the main official distributor for Wuyingdian books—sold 766 copies of books from 1865 to 1871 . Of these, only one-Substatutes for arresting escapees (Dubu zeli 督捕則例)—was a legal book. Although many imperial editions of legal books, including the Great Qing Code and the Expanded substatutes of the Great Qing Code - were listed for sale by the Wuyingdian at reasonable prices (e.g., 1.1-2.5 taels for the Code and 0.08-0.15 taels for the Expanded substatutes), not a single copy sold between 1865 and $1871 .{ }^{74}$ The Wuyingdian, like many other central government agencies, operated inefficiently and expensively. It would take the Wuyingdian several years to finish printing a book in the high Qing, and even longer in the late Qing. Legal books, on the other hand,

72 For the distribution and reprinting of Wuyingdian books, see Yang Yuliang, 'Qingdai zhongyang guanzuan tushu faxing qianxi', in Gugong bowuyuan yuankan 4 (1993): 88, 91. The Qing government did not especially promote the reprinting of imperial editions of legal books, but so far I have not found any evidence suggesting that it forbade such reprints.

73 Lei Jin 雷瑨 (1871-1941) recorded the prices for Wuyingdian books sold in Liulichang bookstores in the late Qing: 'Wuyingdian editions are sold according to the number of volumes (ce 冊). For each volume, it costs one or two taels of silver' (Wang Yeqiu, Liulichang shihua, 34).

74 'Qing Tongzhi Guangxu nianjian Wuyingdian maishu dibu' 清同治光緒年間武英殿買 書底簿 and 'Wuyingdian tongxing shuji mulu qingce' 武英殿通行書籍目錄清冊, reprinted in Weng Lianxi, Qing neifu keshu dang'an shiliao huibian (Yangzhou: Guangling shushe, 2007), 689-721, 738-51. 
required frequent updating when the court promulgated new laws. When the Wuyingdian finished printing a legal book, there was a good chance that it was already obsolete. ${ }^{75}$ Therefore, Beijing commercial publishers chose to not reprint these outdated and unpopular imperial editions of legal books, even though they had convenient access to them.

If they did not use Wuyingdian editions, where did Beijing commercial publishers obtain legal texts for reprinting? Among the 44 editions of legal books with identifiable origins, 17 were from Jiangnan (ten from Hangzhou, three from Suzhou, two from Shanghai, one from Nanjing, one from Haining), five from Hubei, three from Guangdong, two from Shanxi, one from Sichuan, one from Fujian. All of the five editions from Hubei were reprints of the Comprehensive compilation of a convenient guide to the Great Qing Code (Da Qing lüli huiji bianlan 大清律例彙集便覽), a popular edition of the Code edited by the Hubei Provincial Judicial Bureau (Hubei yanju 湖北獻局). The Hubei Provincial Judicial Bureau edition, however, was based on the famous Comprehensive complete compilation of the Great Qing Code (Da Qing lüli tongzuan jicheng 大清律例統纂集成) editions, originally edited and published in Hangzhou. ${ }^{76}$ Thus editions originating in Jiangnan dominated the Beijing legal book market in the late Qing.

Many Beijing bookstores had close connections with Jiangnan book merchants and publishers. Li Wenzao recorded that some Liulichang bookstore owners were Suzhou and Huzhou 湖州 natives, including Tao shi 陶氏 of the Wuliu ju 五柳居 and Xie shi 謝氏 of the Wencui tang 文萃堂. These bookstores imported a large number of books from Jiangnan, transported by boat by way of the Grand Canal. ${ }^{77}$ As a Korean diplomatic official observed, there were massive shipments of Jiangnan books to Beijing in the mid-Qing:

[The owner] of the Wuliu ju tells me that his book boat (shuchuan 書船) comes from Jiangnan. Now it is anchored in Zhangjiawan 張家灣 in Tongzhou 通州. It will come tomorrow and bring more than 4000 volumes of books. ${ }^{78}$

75 Ting Zhang, 'Information and power', 61-4.

76 Hubei yanju, ed., Da Qing lüli huiji bianlan (Wuhan: Hubei yanju, 1872), 'Xiangwen', ıb-2a.

77 Li Wenzao, 'Liulichang shusi ji', 101-2.

78 Zhangjiawan was an important port on the Grand Canal. Yi Tŏngmu 李德您 (1741-1793) was the author of this paragraph, cited from Yang Yulei, 'Chaoxian Yanxing lu suoji de Beijing Liulichang', in Zhongguo dianji yu wenhua 4 (2004): 60. 
Because of the high demand for books in Beijing, especially during massive book editing projects like the Complete library in four sections in the high Qing, many Jiangsu and Zhejiang book merchants engaged in reselling Jiangnan books to officials and scholars in Beijing. ${ }^{79}$ Although a large percentage of books transported from Jiangnan to Beijing were expensive rare books, these book boats also probably brought new books-including popular editions of legal books - from Jiangnan as well. In 1824, a major flood of the Yellow River blocked the Grand Canal, which disrupted transportation between Beijing and Jiangnan. ${ }^{80}$ There was a sudden rise in the number of legal books published in Beijing in the Daoguang reign (see Table 1), possibly because Jiangnan books could not easily reach in Beijing, which made publishing and reprinting legal texts in Beijing more profitable.

Besides Jiangnan, Beijing book merchants also imported a large number of old and new books from other provinces. Li Wenzao mentioned that all the Liulichang bookstores owned by Jiangxi merchants were selling new books in the mid-Qing. ${ }^{81}$ These Jiangxi natives most likely printed these books in Jiangxi and transported them to Beijing for sale. Lun Ming 倫明 (1875-1944) recorded that Beijing book merchants searched for books everywhere and brought valuable editions back to Beijing for sale in the late Qing:

[These book merchants] start from Zhili, Henan, Shandong, Shanxi; and then [they will go to] Jiangsu, Zhejiang, Fujian, Guangdong, Hunan, Hubei; and then Sichuan, Shaanxi, Gansu ... If they go to faraway places, they will have one round trip per year. If they go to nearby places, they will have three or four round trips per year. ${ }^{82}$

As one of the hubs both of the national book market and the transportation network in late imperial China, Beijing enjoyed convenient access to valuable and popular editions of books published in other printing centers.

Thanks to its national networks of books and merchants, Beijing publishers had convenient access to the finest editions of legal books around the empire. In most instances, rather than compiling their own editions or reprinting Wuyingdian imperial editions, they chose to follow and reprint editions originally published in Jiangnan. The circulation of legal books between

79 See Sun Dianqi, Liulichang xiaozhi, 4.

80 Ni Yuping, Qingdai caoliang haiyun yu shehui bianqian (Shanghai: Shanghai shudian chubanshe, 2005), 49-50.

81 Li Wenzao, 'Liulichang shusi ji', 100-2.

82 Lun Ming, 'Xushu lou ji'; cited from Sun Dianqi, Liulichang xiaozhi, 13. 
the imperial capital and Jiangnan went in one direction only. While Beijing publishers enthusiastically reprinted Jiangnan editions, Jiangnan commercial publishers had little interest in reproducing Beijing legal books. In my list of 60 legal books, none of the editions originating in Beijing were reproduced in Jiangnan. Nor did Jiangnan commercial publishers show any interest in copying imperial editions of legal books including even the Qing Code. In my research on commercial publications of the Qing Code, I found at least 53 commercial editions of the Code published in Jiangnan, including 33 editions published in Hangzhou, 9 in Shanghai, 7 in Suzhou, 2 in Nanjing, 1 in Ningbo, and 1 in Changzhou. ${ }^{83}$ Commercial publishers in Jiangnan rarely reprinted Wuyingdian imperial editions, nor did they follow the content and style of imperial editions. Instead of using the same single-register (danlan 單欄) per page printing format as the imperial editions did, commercial publishers divided each page into three horizontal registers and enriched the content with private commentaries, administrative regulations, and case precedents, which the imperial editions did not contain. Beijing commercial publishers too rejected Wuyingdian editions and closely followed Jiangnan editions. ${ }^{84}$ All the 15 commercial editions of the Code published in Beijing after 1800 were reprints which followed the content and style of Jiangnan editions.

\section{Beijing Legal Books: Who Bought Them and for How Much?}

Beijing bookstores sold commercial editions of legal books at affordable prices. The earliest edition of the Qing Code published in Beijing for which we have price information is the Newly revised comprehensive compilation of the Great Qing Code (printed by the Diqisuo guanfang in 1832), which sold for 6 taels of silver. The price remained the same for the 1836 and 1841 editions of the book published by the same publisher. ${ }^{85} \mathrm{~A}$ similar commercial edition of the Code, published by anonymous publishers in Liulichang in 1859 and reprinted in 1872 , sold for 6.4 taels. ${ }^{86}$ The Diqisuo guanfang printed a new edition of the

\footnotetext{
83 Ting Zhang, 'Information and power', 137.

84 Ibid., 83-155. See also Ting Zhang, 'Marketing legal information', 236-50.

85 Da Qing lüli chongding huitong xinzuan (Beijing: Diqisuo guanfang, 1832, reprinted in 1836 and 1841), front page.

86 Yao Run, Da Qing lüli zengxiu tongzuan jicheng (Beijing: Liulichang, 1859 and 1872), front colophon page.
} 
Code in 1873, which sold for 6.4 taels. ${ }^{87}$ The price of the Code remained almost the same from the Daoguang to the Guangxu period. In 1892, an anonymous publisher in Beijing republished the Comprehensive compilation of a convenient guide to the Great Qing Code and sold it for 6 taels. ${ }^{88}$ Since these commercial editions of the Code were huge books, usually containing over 40 chapters, the prices were not high.

Note that the prices of commercial editions of the Code in Beijing were similar to the prices in Hangzhou, where many Beijing editions originated. For example, the Expanded comprehensive complete compilation of the Great Qing Code, printed by the Sanyu tang 三餘堂 in Hangzhou in 1836 and 1838, also sold for 6.4 taels. ${ }^{89}$ Another influential edition of the Code, published by the Juwentang 聚文堂 bookstore in Hangzhou in 1896, 1898, and 1907-consistently sold for 6.4 taels. ${ }^{90}$ The similarity of not only the content and printing style, but also the book prices in Beijing and Hangzhou suggests the integration of the legal book market and book culture in the late Qing.

An advertisement for legal books sold by the Ronglu tang, contained in the 1892 winter edition of the Complete book of the official directory (Jinshen quans$h u$ 搢紳全書), provides valuable information on the prices of legal books in the late Qing. The advertisement lists 16 books sold by the Ronglu tang and gives their prices (See Table 2). The prices ranged from 0.2 taels to 9 taels, usually according to the length of the books. The most expensive book was $A$ conspectus of judicial cases, original edition and continuation (Zhengxu xing'an huilan 正續刑案匯覽), a huge book with nearly 100 chapters, which sold for 9 taels. The majority of books on the list were on sale for less than one tael. The Brief guide to the statutes and substatutes, a legal handbook with eight chapters, sold for one tael. The price for Essential words of the Great Qing Code (Da Qing lüli jingyan 大清律例精言), a small book consisting of only one volume, was only 0.2 taels. Some books on the list were surprisingly inexpensive. For example, the Complete book concerning happiness and benevolence, a relatively long book with 32 chapters, sold for only 0.7 taels. Generally speaking, the prices

87 Yao Run, Da Qing lüli huitong xinzuan (Beijing: Diqisuo guanfang, 1873), reprinted in Shen Yunlong, Jindai Zhongguo shiliao congkan, Series 3, vol. 22 (Taipei: Wenhai chubanshe, 1987), front colophon page.

88 Da Qing lüli huiji bianlan (Beijing, 1892), front colophon page.

89 Yao Run, Da Qing lüli zengxiu tongzuan jicheng (Hangzhou: Sanyu tang, 1836 and 1838), front colophon page.

$90 \quad$ Yao Run, Da Qing lüli zengxiu tongzuan jicheng (Hangzhou: Juwen tang, 1896, 1898, and 1907), front colophon page. For further discussion of the prices of the Code, see Ting Zhang, 'Information and power', 135-6. 
of Ronglu tang legal books were quite reasonable. The opening paragraph of the advertisement announced that these books were 'sold at reduced prices' (jianjia fashou 減價發售) in the Ronglu tang bookstore.

TABLE 2 Ronglu tang's legal books and their prices $(1892)^{91}$

$\begin{array}{ll}\text { Title } & \text { Price (liang) }\end{array}$

\begin{tabular}{ll}
\hline Xinzeng Da Qing li 新增大清例 & 6 \\
Libu sisi zeli 吏部四司則例 & 8 \\
Zhengxu xing'an huilan 正續刑案匯覽 & 9 \\
Libu zeli 禮部則例 & - \\
Xinke Xingbu xinzhang 新刻刑部新章 & 1 \\
Lüli bianlan 律例便覽 & 1 \\
Xinke muling quanshu 新刻牧令全書 & 1.8 \\
Liubu chufen zeli 六部處分則例 & 1.8 \\
Xinke Xiyuanlu xiangyi 新刻洗冤錄詳義 & 1 \\
Yongliyongyan 庸吏庸言 & 0.3 \\
Xinke wupi Xiyuanlu 新刻五批洗冤錄 & 1 \\
Mingfa zhizhang 名法指掌 & 0.3 \\
Xinke huanhai zhinan 新刻宦海指南 & 0.5 \\
Fuhui quanshu 福惠全書 & 0.7 \\
Xinke lülijingyan 新刻律例精言 & 0.2 \\
Zoudui hebian 奏對合編 & 0.3 \\
&
\end{tabular}

Based on my sample of 60 Beijing editions, we may estimate that the target consumers of Beijing legal books were officials and scholars, especially newly appointed magistrates and prefects like Yanchang, who would have to handle legal and administrative affairs in their jurisdiction. For example, in the Brief guide for judging criminal cases, reprinted respectively by the Shenyi tang and the Ronglu tang in Beijing in the late Qing, the editor pointed out that scholars usually paid little attention to laws and regulations when pursuing examination degrees. After they passed the exams and got official appointments, however, they often had to deal with legal cases on a daily basis. Many could not help

91 The information given here is taken from the front advertisement page of Jinshen quanshu (winter 1892). 
but feel perplexed and confused because they were not familiar with the laws. The editor proclaimed that reading his book would greatly help new officials learn the laws and judicial skills. Even experienced officials would also find the book extremely helpful. ${ }^{92}$ 'Confucians' (ruzhe 儒者), 'scholars' (shiren 士人), 'magistrates' (muling 牧令), 'gentlemen who get official appointments' (tongji zhu junzi 通籍諸君子), and 'newly appointed officials' (chushe shitu 初涉仕途) were frequently mentioned as target readers in prefaces of Beijing legal books. Although Beijing books were certainly more expensive than books produced in many other places, especially rural printing centers like Sibao, they only cost a small fraction of the annual salaries of their main target readers. ${ }^{93}$

Even though these legal books targeted officials and scholars, they were sold openly in bookstores, available to anyone who could afford to buy them. The real audience probably extended far beyond officials and scholars. When examining the readership of official directories sold in Beijing bookstores, Kan Hongliu found that although these books were aimed at officials and scholars, many other social groups also read and used these books, including merchants, foreign missionaries, and even commoners such as cart drivers (chefu 車夫) in Beijing. ${ }^{94}$ The same was probably true of Beijing legal books. There were many potential readers for them, such as clerks and runners, merchants, pettifoggers, litigants, and so on. Thanks to commercial publishers in Beijing, these legal books were widely available in the book market and convenient for readers to buy. This contributed to the dissemination of accurate and up-to-date legal knowledge from the state to society.

\section{Conclusion}

The story of commercial legal publications in Beijing illustrates the geographic mobility of printed texts, manuscripts, publishers, craftsmen, and readers in late imperial China. It also sheds lights on the connections and competition that linked Beijing to other printing centers in places like Jiangnan and Jiangxi. Sojourning book merchants dominated the Beijing book market and their ties to their native places significantly influenced Beijing publishers' business practices. Beijing bookstore owners imported old and new books from their hometowns in Jiangnan, Jiangxi, and elsewhere; they sometimes sent manuscripts

\footnotetext{
92 Mingshan, ed., Zheyu bianlan (1850), 'Preface', 1b-2a.

93 For detailed information about book prices in Sibao, see Brokaw, Commerce in culture, 513-8.

94 Kang Hongliu, 'Jinshen lu yu Qingdai Beijing', 57.
} 
to other places for printing to reduce the cost of publishing. In addition, native place connections also facilitated the formation of a book merchant guild in Liulichang, which enhanced cooperation and reduced competition among publishers.

Thanks to the quantity and flow of texts in the national book market, Beijing publishers had convenient access to fine editions of legal books. They could select from different editions and they reprinted the best and most popular ones to sell for profit. Although Beijing publishers had a close relationship with the Wuyingdian imperial publishing house, they chose Jiangnan (especially Hangzhou) editions of legal books over Wuyingdian editions. In the course of the Qing dynasty, Beijing publishers became increasingly integrated into the national book market. The rise and fall of printing centers in Jiangnan, which exported numerous books to Beijing through the Grand Canal, significantly impacted upon Beijing publishing activities. Beijing legal publishers reduced their own compilation activities and began to reprint Jiangnan editions in the early 19th century when Jiangnan editions rose to dominance in the Qing legal book market. During the Taiping War, which destroyed many important printing centers in Jiangnan, Beijing publishers took the opportunity to expand their business.

In the late Qing, Beijing was a flourishing legal printing center, selling a variety of legal books at affordable prices to officials, scholars, and others who wanted to learn the law. Readers could easily build a comprehensive legal library and get access to the latest laws and regulations, as well as take these books to remote and undeveloped areas where books were difficult to find, as the official Yanchang did when he was dispatched to Guangxi. Beijing commercial legal publishers thus contributed to the dissemination of accurate and up-to-date legal information in late imperial China.

\section{Bibliography}

Beijing Gongye zhi bianzuan weiyuanhui 北京工業志編纂委員會, ed., Beijing gongye zhi: yinshua zhi 北京工業志: 印刷志 (Beijing: Zhongguo kexue jishu chubanshe, 2001).

Beijingshi difangzhi bianzuan weiyuanhui 北京市地方志編纂委員會, ed., Beijing zhi: chuban zhi 北京志: 出版志 (Beijing: Beijing chubanshe, 2005).

Brokaw, Cynthia J., Commerce in Culture:The Sibao book trade in the Qing and Republican periods (Cambridge MA: Harvard University Press, 2007).

Chen Chongyuan 陳重遠, Liulichang shihua 琉璃廠史話 (Beijing: Beijing chubanshe, 2015). 
Chen Qingzi 陳慶滋, Juguan yaoze 居官要則 (Beijing: Longyun zhai, nd).

Da Qing lüli chongding huitong xinzuan 大清律例重訂會通新纂 (Beijing: Diqisuo guanfang, 1832; reprinted in 1836 and 1841).

Da Qing lüli huiji bianlan 大清律例匯輯便覽 (Wuhan: Hubei yanju, 1872). Reprinted in Beijing: by Shancheng tang in 1877 and 1888 and by an anonymous publisher in 1892 .

Du Xinfu 杜信孚 and Du Tongshu 杜同書, Quan Ming fensheng fenxian keshu kao (Beijing juan) 全明分省分縣刻書考 (北京卷) (Beijing: Xianzhuang shuju, 2001).

Feng Wei 馮偉, 'Qingdai Beijing Liulichang keshu yanjiu清代北京琉璃廠刻書研究', unpublished M.A. thesis (Beijing yinshua xueyuan, 2011).

Huang Liuhong 黃六鴻, Fuhui quanshu 福惠全書 (Beijing: Shatuyuan wenchang huiguan, 1893).

Jinshen quanshu 搢紳全書 (Beijing: Ronglu tang, winter 1892).

Kan Hongliu闒紅柳, 'Jinshen lu yu Qingdai Beijing 搢紳錄與清代北京', Beijing dang'an 北京檔案 10 (2013): 55-7.

Kishimoto Mio 岸本美緒, Gu Qisha 顧其莎 trans., 'Guanyu Qingdai qianqi dingli ji de liyong 關於清代前期定例集的利用', in Xu Shihong 徐世虹, ed., Zhongguo gudai falü wenxian yanjiu 中國古代法律文獻研究, vol. 8 (Beijing: Shehui kexue wenxian chubanshe, 2014).

Li Hua 李華, ed., Ming Qing yilai Beijing gongshang huiguan beike xuanbian 明清以來 北京工商會館碑刻選編 (Beijing: Wenwu chubanshe, 1980).

Li Zhen 李珍, Dingli quanbian 定例全編 (Beijing: Rongjin tang, 1715).

Li Zhen 李珍, Dingli quanbian xuzeng xinli 定例全編續增新例 (Beijing: Rongjin tang, 1723).

Liang Maoxiu 梁禁修, Dingli xubian 定例續編 (Beijing: Rongjin tang, 1745).

Liu Qiang 劉蔷, 'Ronglu tang yu Qingdai jinshen lu zhi chuban 榮錄堂與清代搢紳錄之 出版', Tushuguan zazhi 圖書館雜誌, 27.10 (2008): 63-8.

Liu, Cheng-yun 劉錚雲, 'Anji jincheng yulan yu Qingdai jinshen lu de kanxing 按季進 呈御覽與清代搢紳錄的刊行', Zhongyang yanjiuyuan lishi yuyan yanjiusuo jikan 中央研究院歷史語言研究所集刊, 87.2 (2016): 345-74.

Mingshan 明善, ed., Zheyu bianlan 折獄便覽 (np: 1850).

Mokros, Emily C., 'Communication, empire, and authority in the Qing gazette', unpublished Ph.D. dissertation (Johns Hopkins University, 2016).

Mokros, Emily C., 'Reading the guides, directories, manuals, and anthologies of Liulichang, in this volume of EAPS.

Ni Yuping 倪玉平, Qingdai caoliang haiyun yu shehui bianqian 清代漕糧海運與社會 變遷 (Shanghai: Shanghai shudian chubanshe, 2005).

Qing shilu 清實錄 (Beijing: Zhonghua shuju, 1985).

Reed, Christopher A., 'Dukes and nobles above, scholars below: Beijing's old booksellers' district Liulichang, 1796-1941-and its influence on 2oth-century Shanghai's book trade', East Asian Publishing and Society 5 (2015): 74-128. 
Sun Dianqi 孫殿起. Liulichang xiaozhi 琉璃廠小志 (Beijing: Beijing guji chubanshe, 1982).

Sun Donghu 孫東虎, Liulichang 琉璃廠 (Beijing: Beijing chubanshe, 2005).

Su Yigong 蘇亦工, 'Faxue suo guancang Da Qing lü tiyao 法學所館藏大清律提要’, Falü wenxian xinxiyu yanjiu 法律文獻信息與研究 4 (2007): 7-9.

Tao Jun 陶駿 and Tao Nianlin 陶念霖, eds., Da Qing lüli zengxiu tongzuan jicheng 大清 律例增修統纂集成 (Hangzhou: Juwen tang, 1896, 1898, 1907).

Wang Yeqiu 王治秋, Liulichang shihua 琉璃廠史話 (Beijing: Sanlian shudian, 1963).

Wan'gu zhai zhuren 萬古齊主人, Da Qing lü zhuzhu guanghui quanshu 大清律朱注廣 匯全書 (Beijing: Wan'gu zhai, nd [the Kangxi period]).

Weng Lianxi 翁連溪, Qing neifu keshu dang'an shiliao huibian 清內府刻書檔案史料彙 編 (Yangzhou: Guangling shushe, 2007).

Will, Pierre-Étienne, ed., Official handbooks and anthologies of imperial China: a descriptive and critical bibliography (Leiden: Brill, forthcoming).

Xue Yunsheng 薛允升, Duli cunyi 讀例存疑 (Beijing: Hanmao zhai, 1905).

Yanchang 延昌, Shiyi xuzhi 事宜須知; reprinted in Guanzhen shu jicheng bianzuan weiyuanhui 官筬書集成編纂委員會, ed., Guanzhen shu jicheng 官筬書集成 (Hefei: Huangshan shushe, 1997).

Yang Yulei 楊雨蕾, ‘Chaoxian Yanxing lu suoji de Beijing Liulichang 朝鮮燕行錄所記的 北京琉璃廠', Zhongguo dianji yu wenhua 中國典籍與文化 4 (2004): 55-63.

Yang Yuliang 楊玉良, 'Qingdai zhongyang guanzuan tushu faxing qianxi 清代中央官纂 圖書發行淺析', Gugong bowuyuan yuankan 故宮博物院院刊 4 (1993): 87-92.

Yang Yuliang 楊玉良, 'Wuyingdian Xiushuchu ji Neifu xiushu geguan 武英殿修書處及 內府修書各館', Gugong bowuyuan yuankan 故宮博物院院刊 1 (1990): 28-40.

Yang Xianmei 楊先梅, et al., Yang Shoujing tiba shuxin yigao 楊守敬題跋書信遺稿 (Chengdu: Bashu shushe, 1996).

Yao Kaiyuan 姚凱元, Juguan bidu shu 居官必讀書 (Beijing: Longyun zhai, nd).

Yao Run 姚潤, et al., Da Qing lüli huitong xinzuan 大清律例會通新纂 (Beijing: Diqisuo guanfang, 1873); reprinted in Shen Yunlong 沈雲龍, et al., Jindai Zhongguo shiliao congkan 近代中國史料叢刊, Series 3, vol. 22 (Taipei: Wenhai chubanshe, 1987).

Yao Run 姚潤, Da Qing lülizengxiu tongzuanjicheng 大清律例增修統纂集成 (Hangzhou: Sanyu tang, 1836 and 1838; Beijing: Liulichang, 1859 and 1872).

Zhang, Ting, 'Information and power: printing, law, and the making of Chinese legal culture, 1644-1911', unpublished Ph.D. dissertation (Johns Hopkins University, 2014).

Zhang, Ting, 'Marketing legal information: commercial publications of the Great Qing Code, 1644-1911', in Li Chen and Madeleine Zelin, eds. Chinese law: knowledge, practice, and transformation, 1530 s to 1950 (Leiden: Brill, 2015).

Zhang, Ting, 'Lüdian, muyou, yu shushang: lun Qingdai Jiangnan falü shuji de chuban yu liutong 律典, 幕友, 與書商: 論清代江南法律書籍的出版於流通', Zhejiang daxue xuebao 浙江大學學報 45.1 (2015): 48-59. 
Zhang Xiumin 張秀民, Zhongguoyinshua shi 中國印刷史 (Shanghai: Shanghai renmin chubanshe, 1989).

Zhongguo renmin zhengzhi xieshang huiyi Beijingshi weiyuanhui wenshi ziliao yanjiu weiyuanhui 中國人民政治協商會議北京市委員會文史資料研究委員會, ed., Wenshi ziliao xuanbian 文史資料選編 (Beijing: Beijing chubanshe, 1984).

Zhu Saihong 朱賽虹, 'Qing wanqi Wuyingdian Xiushuchu "xiushu” yu "fei xiushu" zhi'neng de xiaozhang-jiyu Qinggong dang'an de kaocha 清代晚期武英殿修書處 “修書” 與 “非修書” 職能的消長一基於清宮檔案的考察, Zhongguo chubanshiyanjiu 中國出版史研究 2 (2015): 137-55. 